\title{
Gene effects for specific leaf area and harvest index in three crosses of groundnut (Arachis hypogaea)
}

\author{
By S N NIGAM ${ }^{1}$, H D UPADHYAYA ${ }^{1 *}$, S CHANDRA ${ }^{1}$, R C NAGESWARA RAO ${ }^{2}$, G C WRIGHT $^{3}$ \\ and A G S REDDY ${ }^{1}$ \\ ${ }^{1}$ International Crops Research Institute for the Semi-Arid Tropics (ICRISAT), Patancheru 502324, Andhra \\ Pradesh, India \\ ${ }^{2} J B$ Petersen Research Station, Department of Primary Industries, Kingaroy, Qld 4610, Australia \\ ${ }^{3}$ Queensland Dept. of Primary Industries, Farming Systems Institute, PO Box 23, Kingaroy, Qld 4610, \\ Australia
}

(Accepted 31 July 2001; Received 30 May 2001)

\begin{abstract}
Summary
Groundnut productivity is low in the semi-arid tropics mainly because of drought caused by low and erratic rainfall. Genotypes that have ability to use limited available water efficiently are required to enhance productivity of the crop. In groundnut, water use efficiency (WUE) is correlated with specific leaf area (SLA). The latter can be used as a surrogate trait for selecting for WUE. Partitioning of assimilates as measured by the harvest index (HI) has the greatest effect on pod yield. In order to improve SLA and in turn WUE and HI, a good knowledge of genetic systems controlling the expression of these traits is essential for the choice of an efficient breeding procedure. This study was conducted to investigate inheritance of SLA and HI in three crosses involving Chico, TMV 2 NLM, and ICGV 86031 groundnut genotypes. The study included parents, $\mathrm{F}_{1}, \mathrm{~F}_{2}$, and backcross generations. Generation means analysis indicated that the additive effects were more important than the dominance effects in the expression of SLA and HI. In addition to additive and dominance effects, additive $\times$ additive type of epistasis, which can be fixed in groundnut (a self pollinated crop), was also significant for SLA in all the three and for HI, in two crosses. The selection for SLA and HI can be effective in early generations in some crosses and to exploit the additive $\times$ additive type of interaction, it can be done in large populations of later generations.
\end{abstract}

Key words: Peanut, water-use efficiency, drought, generation mean analysis, additive and dominance gene effects, epistasis

\section{Introduction}

Groundnut is an annual legume grown primarily for high quality edible oil (36\% to $54 \%$ on dry matter basis) and easily digestible protein (12\% to $36 \%)$ in its seeds. It is cultivated in over 100 countries in tropical, sub-tropical and warm temperate regions of the world. The crop is grown on about 23.8 million ha world wide with an estimated total production of 24.5 million $t$ in shell and an average productivity of $1.44 \mathrm{t} \mathrm{ha}^{-1}$ (Anon., 2000). Developing countries account for $97.2 \%$ of the area and $94.8 \%$ of the groundnut production in the world.

Groundnut is grown in both high-input commercial and subsistence farming systems. Under low-input systems, average yields are about $0.7-0.8 \mathrm{t} \mathrm{ha}^{-1}$ and can vary substantially from year to year. Under highinput systems, yields average 2-4 $\mathrm{t} \mathrm{ha}^{-1}$ and are more stable than low-input systems. Drought is the major factor responsible for low productivity under lowinput conditions. However, under a commercial system, water may also be a limiting factor. For both situations, cultivars that are efficient in water utilisation are required.

In a biological model (Passioura, 1986), seed yield is a function of water transpired (T), water-use efficiency (WUE), and harvest index (HI). Studies have shown substantial genetic variation in each of these components contributing to seed yield in groundnut (Wright, 1994). The WUE, defined as total biomass production per unit of water transpired $\left(\mathrm{g} \mathrm{kg}^{-1}\right)$, is not an easy trait to measure. It is virtually impossible to include such a trait in breeding programmes. However, several researchers (Farquhar et al., 1982; Hubick et al., 1986; Wright et al., 1988; Wright et al., 1994) have found WUE to be negatively correlated with leaf carbon isotopic composition $(\Delta)$ in a range of crop species including groundnut, raising the possibility of its use in selection for high water-use efficient genotypes. But the facilities for $\Delta$ analysis are not available everywhere and it is expensive to analyse large 
numbers of plants in segregating populations. Based on an $\mathrm{F}_{2}$ distribution, quantitative inheritance was suggested for $\Delta$ by Hubick et al. (1988). Meanwhile, Wright et al. (1988) and Wright et al. (1994) observed that specific leaf area (SLA, $\mathrm{cm}^{2} \mathrm{~g}^{-1}$, which is negatively related to leaf thickness) was closely and negatively correlated with WUE over a wide range of cultivars and environments in groundnut. This suggested that SLA could be used as a surrogate for selecting for WUE in groundnut breeding programmes. SLA is simple and inexpensive to measure. There is only one published report on the genetic control of SLA in groundnut (Jayalakshmi et al., 1999). In a diallel study involving seven parents, Jayalakshmi et al. (1999) reported predominance of additive gene effects and identified breeding lines TMV 2 NLM and ICGV 86031 as good general combiners for SLA.

In self-pollinated crops, simultaneous selection for a superior rate of biomass accumulation and high $\mathrm{HI}$, and a length of time to harvest maturity that is neither shorter nor longer than the duration of the growing season, has been suggested for increasing yield (Wallace et al., 1993). Duncan et al. (1978) reported that the partitioning of assimilates as measured by HI had the greatest effect on pod yield in groundnut. The increase in groundnut yield in future might be accomplished by developing cultivars with a combination of high reproductive efficiency, HI, and total flower count (Coffelt et al., 1989). For HI, a low to moderate variation has been reported in groundnut (Dhopte \& Zade, 1981; Murty et al., 1983; Velu \& Gopalakrishnan, 1985; Sharma \& Varshney, 1995), indicating the possibility to select for this trait to improve groundnut yield. However, there are very few and conflicting reports concerning information on genetic control of HI in groundnut. Makne (1992) reported non-additive genetic variance and Dwivedi et al. (1998) general combining ability effects for the expression of this trait.

The primary objective of this study was to estimate the relative importance of additive and non-additive gene effects in controlling the inheritance of SLA and $\mathrm{HI}$ in three crosses in groundnut. This information will help in formulating appropriate breeding strategies to develop high yielding, wateruse efficient groundnut genotypes.

\section{Materials and Methods}

Three groundnut genotypes: Chico, ICGV 86031, and TMV 2 NLM were selected for this study. Chico is an early maturing Spanish (subsp. fastigiata var. vulgaris) germplasm line (Bailey \& Hammons, 1975). ICGV 86031 is an elite Spanish germplasm line derived from a cross, involving F334A-B-14 and NC Ac 2214 (Dwivedi et al., 1993). TMV 2 NLM is an induced narrow leaf mutant (NLM) of an Indian Spanish cultivar, TMV 2. These genotypes represented the spectrum of available variation for SLA and HI (ICRISAT, unpublished data). Chico has high SLA and high HI, ICGV 86031 low SLA and medium HI, and TMV 2 NLM medium SLA and low HI.

Chico, ICGV 86031, and TMV 2 NLM were crossed in all possible combinations including reciprocals in the glasshouse in the 1997 rainy season. Each of the resultant six $F_{1}$ hybrids was crossed to both the parents to generate $12 \mathrm{BCF}_{1}$ and selfed to produce six $\mathrm{F}_{2}$ populations in the 1998 rainy season.

The experiment was planted on $60 \mathrm{~cm}$-ridges in the 1998-99 post-rainy season in alfisols-Patancheru Series (Udic Rhodostolf) soil in a split plot design with three replications. The three cross combinations constituted main plots. There were 10 sub-plots consisting of two parents, two $\mathrm{F}_{1} \mathrm{~s}$, two $\mathrm{F}_{2} \mathrm{~s}$, and four $\mathrm{BCF}_{1} \mathrm{~s}$ within a main plot. The size of sub-plots varied with generations. The parents and $\mathrm{F}_{1} \mathrm{~s}$ were represented with one row each, $\mathrm{BCF}_{1} \mathrm{~s}$ with two rows each, and $\mathrm{F}_{2} \mathrm{~s}$ with eight rows each of $4 \mathrm{~m}$ length. The distance between plants within a row was 15 $\mathrm{cm}$. Care was taken to ensure uniform $5 \mathrm{~cm}$ depth of planting. Seeds were treated with ethrel (2chloroethylphosphonic acid) before planting to overcome the possible effects of postharvest seed dormancy of TMV 2 NLM in its cross combinations. The experiment received $60 \mathrm{~kg} \mathrm{P}_{2} \mathrm{O}_{5} \mathrm{ha}^{-1}$ at the time of planting, $400 \mathrm{~kg}$ gypsum ha ${ }^{-1}$ at the peak flowering stage, and 10 irrigations ( $5 \mathrm{~cm}$ water per irrigation) during the cropping season. The experiment was fully protected against diseases and insect pests. Ten competitive plants in each parent and $\mathrm{F}_{1}, 70$ plants in each $\mathrm{BCF}_{1}$, and 200 plants in each $\mathrm{F}_{2}$ population were selected randomly in each replication to record observations. The fully expanded, healthy second leaf (in case of damage, the third leaf) from the apex of the main stem in each selected plant was sampled 90 days after planting in morning hours and brought to the laboratory soon after in plastic bags. The area of each leaf was measured using a computerised image analyzer (LI-COR, Model LI-3100). The leaf samples were oven dried at $60^{\circ} \mathrm{C}$ for 2 days before recording leaf dry weight. The SLA was determined as the ratio of leaf area to leaf dry weight $\left(\mathrm{cm}^{2} \mathrm{~g}^{-1}\right)$.

The selected plants were harvested individually in each plot at maturity and observations on vegetative (above ground parts) and pod weight were recorded. All pods (including immature pods) were detached from the plant and bulked together with pods recovered from the soil. Pods and the remaining plant parts were oven dried separately at $60^{\circ} \mathrm{C}$ until a constant weight was achieved for each. Pod weight was multiplied with a correction factor of 1.65 (Duncan et al., 1978) to adjust for the differences in 
the energy requirement for producing pod dry matter compared to vegetative parts. The HI was determined as a ratio of adjusted pod weight to biomass, where adjusted pod weight $=$ pod weight $\times 1.65$ and biomass $=$ adjusted pod weight + vegetative weight.

The analysis of variance was performed on data for SLA and HI. The means of $\mathrm{F}_{1}, \mathrm{~F}_{2}$, and $\mathrm{BCF}_{1}$ were compared with their reciprocals to find out whether reciprocal differences were significant. If the reciprocal differences were non-significant, the data were combined for generation means analysis. The means and variances were estimated for every generation for each cross from individual plant data and estimates of genetic effects were determined. The joint scaling test (Cavalli, 1952) was conducted to obtain information on the nature of gene effects involved in SLA and HI. The parameters were estimated by weighted least squares, in which the weight attached to each generation mean was the amount of information that mean contributed and it was calculated as the inverse of its variance. The use of weighted least square analysis reduces the error mean square associated with the segregating generations that contain a greater number of individuals than the non-segregating generations. The parameters estimated were $\mathrm{m}$ (mean), $\mathrm{d}$ (pooled additive effects), $\mathrm{h}$ (pooled dominance effects), $\mathrm{i}$ (the pooled additive $\times$ additive epistatic effects), $j$ (the pooled additive $\times$ dominance effects), and 1 (the pooled dominance $\times$ dominance effects). The standard error for each of the six parameters was estimated and the significance of each parameter was tested using a ' $t$ ' test.

The stepwise regression analysis was used to find the best fit model as suggested by Torres et al. (1993). The Chi squared test proposed by Mather \& Jinks (1971) was discarded, since according to the additive model only parents $\left(\mathrm{P}_{1}, \mathrm{P}_{2}\right)$ and $\mathrm{F}_{1}$ generations are independent, and the mean value of the $\mathrm{F}_{2}$ and other generations are functions of $\mathrm{m}, \mathrm{d}$, and $h$. Thus, the addition of $F_{2}$ and other generations will inflate Chi squared values (Torres et al., 1993).

Information on the relative importance of the gene effect estimates was obtained by partitioning the model sum of squares into each significant parameter with one degree of freedom. The percentage of the overall model sum of squares attributed to a parameter indicated its contribution in explaining the variation for a trait. In estimating the relative importance of parameters, the method of partitioning sum of squares into different component parameters is superior to the one using coefficient of determination by sequentially entering parameters into the model. In the latter method, the order that each genetic effect is entered is important and the effects entered first may be overestimated, while those entered last may be underestimated (CukaderOlmedo \& Miller, 1997).

\section{Results and Discussion}

Since the reciprocal differences for means of $\mathrm{F}_{1}$, $\mathrm{F}_{2}$ and $\mathrm{BCF}_{1}$ were not significant, the data were pooled for further analyses.

In all the three crosses, means of the $\mathrm{F}_{1}$ and $\mathrm{F}_{2}$ generations for SLA lay between the parental means (Table 1). The mean SLA for the $F_{1}$ generation of the Chico $\times$ TMV 2 NLM cross $(178.0 \pm 2.51)$ was $5.2 \%$ more than the mid parental value, whereas in Chico $\times$ ICGV 86031 cross $(156.2 \pm 2.50)$ it was $6.0 \%$ less than the mid parental value, and in the third cross TMV 2 NLM $\times$ ICGV 86031 (140.3 \pm 1.55), it was near to the mid parental value. The mean SLA of the $\mathrm{F}_{2}$ generation was higher than that of the $\mathrm{F}_{1}$ generation in the Chico $\times$ ICGV 86031 and TMV $2 \mathrm{NLM} \times$ ICGV 86031 crosses but lower in the Chico $\times$ TMV 2 NLM cross (Table 1). The backcross means were between the $\mathrm{F}_{1}$ and the recurrent parent means or higher than the $\mathrm{F}_{1}$ mean in crosses Chico $\times$ ICGV 86031 and TMV $2 \mathrm{NLM} \times$ ICGV 86031. In the third

Table 1. Mean ( \pm standard error) specific leaf area and harvest index for parents, $F_{1}, F_{2}, B C_{1} P_{1}$ and $B C_{1} P_{2}$ generations of three crosses of groundnut

\begin{tabular}{|c|c|c|c|c|c|c|}
\hline \multirow[b]{2}{*}{ Generation* } & \multicolumn{3}{|c|}{ Specific leaf area } & \multicolumn{3}{|c|}{ Harvest index } \\
\hline & $\begin{array}{c}\text { Chico } \times \text { TMV } 2 \\
\text { NLM }\end{array}$ & $\begin{array}{c}\text { Chico } \times \text { ICGV } \\
86031\end{array}$ & $\begin{array}{l}\text { TMV } 2 \text { NLM } \times \\
\text { ICGV } 86031\end{array}$ & $\begin{array}{c}\text { Chico } \times \text { TMV } 2 \\
\text { NLM }\end{array}$ & $\begin{array}{c}\text { Chico } \times \text { ICGV } \\
86031\end{array}$ & $\begin{array}{c}\text { TMV } 2 \text { NLM } \times \\
\text { ICGV } 86031\end{array}$ \\
\hline $\mathrm{P}_{1}$ & $184.6 \pm 3.11$ & $205.7 \pm 3.01$ & $152.6 \pm 1.62$ & $0.66 \pm 0.010$ & $0.66 \pm 0.010$ & $0.46 \pm 0.012$ \\
\hline $\mathrm{P}_{2}$ & $153.4 \pm 1.81$ & $125.5 \pm 2.11$ & $123.1 \pm 1.15$ & $0.39 \pm 0.012$ & $0.55 \pm 0.010$ & $0.59 \pm 0.011$ \\
\hline $\mathrm{F}_{1}$ & $178.0 \pm 2.51$ & $156.2 \pm 2.50$ & $140.3 \pm 1.55$ & $0.54 \pm 0.015$ & $0.65 \pm 0.010$ & $0.41 \pm 0.010$ \\
\hline $\mathrm{F}_{2}$ & $174.8 \pm 0.93$ & $167.0 \pm 0.97$ & $145.4 \pm 0.77$ & $0.46 \pm 0.005$ & $0.62 \pm 0.003$ & $0.41 \pm 0.004$ \\
\hline $\mathrm{BC}_{1} \mathrm{P}_{1}$ & $170.8 \pm 1.38$ & $189.0 \pm 1.89$ & $152.1 \pm 1.32$ & $0.50 \pm 0.009$ & $0.66 \pm 0.005$ & $0.45 \pm 0.009$ \\
\hline $\mathrm{BC}_{1} \mathrm{P}_{2}$ & $170.0 \pm 1.51$ & $161.9 \pm 1.70$ & $141.1 \pm 1.23$ & $0.43 \pm 0.009$ & $0.61 \pm 0.006$ & $0.45 \pm 0.008$ \\
\hline MP & 169.0 & 165.6 & 137.9 & 0.53 & 0.61 & 0.53 \\
\hline
\end{tabular}

$* \mathrm{P}_{1}=$ parental line $1, \mathrm{P}_{2}=$ parental line $2, \mathrm{~F}_{1}=$ first filial generation of crosses, $\mathrm{F}_{2}=$ second filial generation of crosses, $\mathrm{BC} \mathrm{P}_{1}=$ first backcross generation with parental line $1, \mathrm{BC}_{1} \mathrm{P}_{2}=$ first backcross generation with parental line 2 , and $\mathrm{MP}=$ mid-parent value. 
cross, Chico $\times$ TMV 2 NLM, the means of backcross generations were lower than the means of $F_{1}$ and $F_{2}$ generations (Table 1). These results indicate varying relative importance of dominance deviation and additive effects for SLA in the three crosses.

The mean $\mathrm{HI}$ of the $\mathrm{F}_{1}$ generation in relation to the means of the parents was different in all the three crosses. It was intermediate between the two parents in the case of Chico $\times$ TMV 2 NLM cross, or similar to the high parent Chico in the Chico $\times$ ICGV 86031 cross, and lower than the low parent TMV 2 NLM in the TMV 2 NLM $\times$ ICGV 86031 cross (Table 1 ). The mean of the $F_{2}$ generation in relation to the $F_{1}$ generation also varied among the crosses. In Chico $\times$ TMV 2 NLM and Chico $\times$ ICGV 86031, the $F_{2}$ mean was lower than the $\mathrm{F}_{1}$ but it was similar to the $F_{1}$ mean in TMV $2 \mathrm{NLM} \times$ ICGV 86031. The means of the backcross generations lay between the means of the $\mathrm{F}_{1}$ generation and the recurrent parent in Chico $\times$ ICGV 86031 and TMV 2 NLM $\times$ ICGV 86031 but they were lower than the $\mathrm{F}_{1}$ generation in Chico $\times$ TMV 2 NLM (Table 1). These results indicate a less pronounced role for dominance deviations and a more pronounced role for additive effects for HI.

The regression analysis tested different parameters to find the best fit model to explain genetic control of SLA and HI in the three crosses. Additive effects were important in all the three crosses for SLA and HI (Table 2). They were positive in all the three crosses for SLA and in two crosses for HI. The negative sign of additive effects for HI in TMV 2 $\mathrm{NLM} \times \mathrm{ICGV} 86031$ merely reflects which of the parents was chosen as $\mathrm{P}_{1}$. It has no genetic consequence. Dominance effects were nonsignificant for SLA in the Chico $\times$ TMV 2 NLM cross and for HI, in Chico $\times$ TMV 2 NLM and TMV $2 \mathrm{NLM} \times$ ICGV 86031 crosses. Dominance effects for SLA in the Chico $\times$ ICGV 86031 cross were positive $(27.36 \pm 6.80)$, but were lower than the additive effects $(40.12 \pm 1.84)$. In the TMV 2 NLM $\times$ ICGV 86031 cross, dominance effects (43.9 \pm
13.00) were greater than the additive effects ( 13.91 $\pm 0.87)$. These results indicate differential importance of dominance effects in these two crosses. Dominance effects for HI $(0.17 \pm 0.060)$ appear to be more important than additive effects $(0.05 \pm 0.006)$ in the Chico $\times$ ICGV 86031 cross. These results indicate overdominance for SLA in the TMV 2 NLM $\times$ ICGV 86031 cross and for HI in the Chico $\times$ ICGV 86031 cross (Table 2). The sign of dominance effects is a function of the $F_{1}$ generation mean value in relation to the mid parental value and it indicates which parent is contributing to the dominance effects. For SLA, the dominance effects in the Chico $\times$ ICGV 86031 cross were contributed by the genes from Chico and in TMV 2 NLM $\times$ ICGV 86031 cross by TMV 2 NLM (Tables 1 and 2). For HI, dominance effects in the Chico $\times$ ICGV 86031 cross were contributed by the genes from Chico (Tables 1 and 2).

The results of fitting the model indicate that epistasis was present in all the three crosses both for SLA and HI (Table 2). All the three types of epistatic effects, $\mathrm{i}(-5.09 \pm 2.34), \mathrm{j}(-28.73 \pm 5.45)$, and $1(4.41 \pm 3.57)$ were important in the Chico $x$ TMV 2 NLM cross while in Chico $\times$ ICGV $86031(\mathrm{j}$ $=-28.34 \pm 6.27,1=-36.74 \pm 6.93)$ and TMV 2 NLM $\times \operatorname{ICGV} 86031(\mathrm{i}=5.18 \pm 4.79,1=-36.02 \pm 8.75)$ only two types of epistatic effects (either $i$ or $j$, and 1) were important for SLA (Table 2). Similarly for HI, all three types of epistatic effects were important in the Chico $\times$ TMV 2 NLM cross, $i$ and 1 epistatic effects in the Chico $\times$ ICGV 86031 cross, and $i$ and $\mathrm{j}$ effects in the TMV $2 \mathrm{NLM} \times \mathrm{ICGV} 86031$ cross (Table 2). The genes controlling SLA in Chico $\times$ ICGV 86031 and TMV 2 NLM $\times$ ICGV 86031 crosses and $\mathrm{HI}$ in the Chico $\times$ ICGV 86031 cross showed duplicate interactions as reflected by the opposite sign of $\mathrm{h}$ and 1 in these cases (Table 2) (Mather \& Jinks, 1971).

The variability accounted for by the different estimated effects varied in different crosses for SLA

Table 2. Estimates of gene effects with standard errors for specific leaf area and harvest index in three crosses of groundnut

\begin{tabular}{|c|c|c|c|c|c|c|}
\hline \multirow[b]{2}{*}{ Gene effects* } & \multicolumn{3}{|c|}{ Specific leaf area } & \multicolumn{3}{|c|}{ Harvest index } \\
\hline & $\begin{array}{c}\text { Chico } \times \text { TMV } 2 \\
\text { NLM }\end{array}$ & $\begin{array}{c}\text { Chico } \times \text { ICGV } \\
86031\end{array}$ & $\begin{array}{l}\text { TMV } 2 \text { NLM } \times \\
\text { ICGV } 86031\end{array}$ & $\begin{array}{c}\text { Chico } \times \text { TMV } 2 \\
\text { NLM }\end{array}$ & $\begin{array}{c}\text { Chico } \times \text { ICGV } \\
86031\end{array}$ & $\begin{array}{l}\text { TMV } 2 \text { NLM } \times \\
\text { ICGV } 86031\end{array}$ \\
\hline $\mathrm{m}$ & $172.57 \pm 1.42$ & $165.58 \pm 1.84$ & $132.41 \pm 4.89$ & $0.43 \pm 0.010$ & $0.56 \pm 0.022$ & $0.41 \pm 0.004$ \\
\hline d & $14.81 \pm 1.77$ & $40.12 \pm 1.84$ & $13.91 \pm 0.87$ & $0.13 \pm 0.009$ & $0.05 \pm 0.006$ & $-0.06 \pm 0.008$ \\
\hline $\mathrm{h}$ & NS & $27.36 \pm 6.80$ & $43.90 \pm 13.00$ & NS & $0.17 \pm 0.060$ & NS \\
\hline $\mathrm{i}$ & $-5.09 \pm 2.34$ & NS & $5.18 \pm 4.79$ & $0.09 \pm 0.013$ & $0.05 \pm 0.020$ & $0.11 \pm 0.009$ \\
\hline $\mathrm{j}$ & $-28.73 \pm 5.45$ & $-28.34 \pm 6.27$ & NS & $-0.14 \pm 0.033$ & NS & $0.12 \pm 0.029$ \\
\hline 1 & $4.41 \pm 3.57$ & $-36.74 \pm 6.93$ & $-36.02 \pm 8.75$ & $0.10 \pm 0.021$ & $-0.08 \pm 0.043$ & NS \\
\hline
\end{tabular}

$* \mathrm{~m}=$ mean, $\mathrm{d}=$ sum of additive effects, $\mathrm{h}=$ sum of dominance effects, $\mathrm{i}=$ sum of additive $\times$ additive epistatic effects, $\mathrm{j}=$ sum of additive $\times$ dominance epistatic effects, $1=$ sum of dominance $\times$ dominance epistatic effects. 
Table 3. Variability accounted for by the different components for specific leaf area and harvest index in three crosses of groundnut

\begin{tabular}{|c|c|c|c|c|c|c|}
\hline \multirow[b]{2}{*}{ Gene effects* } & \multicolumn{3}{|c|}{ Specific leaf area } & \multicolumn{3}{|c|}{ Harvest index } \\
\hline & $\begin{array}{c}\text { Chico } \times \text { TMV } 2 \\
\text { NLM }\end{array}$ & $\begin{array}{c}\text { Chico } \times \text { ICGV } \\
86031\end{array}$ & $\begin{array}{l}\text { TMV } 2 \text { NLM } \times \\
\text { ICGV } 86031\end{array}$ & $\begin{array}{c}\text { Chico } \times \text { TMV } 2 \\
\text { NLM }\end{array}$ & $\begin{array}{c}\text { Chico } \times \text { ICGV } \\
86031\end{array}$ & $\begin{array}{l}\text { TMV } 2 \text { NLM } \times \\
\text { ICGV } 86031\end{array}$ \\
\hline d & 55.74 & 88.13 & 84.31 & 72.39 & 81.32 & 19.58 \\
\hline $\mathrm{h}$ & NS & 2.28 & 2.93 & NS & 13.32 & NS \\
\hline $\mathrm{i}$ & 7.97 & NS & 9.23 & 8.92 & 1.96 & 70.88 \\
\hline $\mathrm{j}$ & 30.88 & 3.58 & NS & 7.45 & NS & 7.94 \\
\hline 1 & 1.11 & 2.06 & 2.76 & 9.86 & 3.19 & NS \\
\hline
\end{tabular}

$* \mathrm{~m}=$ mean, $\mathrm{d}=$ sum of additive effects, $\mathrm{h}=$ sum of dominance effects, $\mathrm{i}=$ sum of additive $\times$ additive epistatic effects, $\mathrm{j}=$ sum of additive $\times$ dominance epistatic effects, $1=$ sum of dominance $\times$ dominance epistatic effects

and HI. Additive effects, $d$, accounted for the largest portion of genetic variability for SLA in all the three crosses (Chico $\times$ TMV 2 NLM, 55.74\%; Chico $\times$ ICGV 86031, 88.13\%, and TMV 2 NLM $\times$ ICGV $86031,84.31 \%$ ) and for $\mathrm{HI}$ in two crosses (Chico $\times$ TMV 2 NLM, 72.39\% and Chico $\times$ ICGV 86031, $81.32 \%$ ) (Table 3). The largest contribution of dominance effects was for $\mathrm{HI}(13.32 \%)$ in the Chico $\times$ ICGV 86031 cross (Table 3). The i type epistatic effects, which are fixable, accounted for $70.88 \%$ for $\mathrm{HI}$ in the TMV $2 \mathrm{NLM} \times$ ICGV 86031 cross (Table 3). In earlier studies, Jayalakshmi et al. (1999) reported predominance of additive gene effects for SLA and Makne (1992) predominance of nonadditive gene effects for HI. Two of the parents of this study, ICGV 86031 and TMV 2 NLM, were also included in the study by Jayalakshmi et al. (1999).

The significance of additive effects contributing to SLA and HI in all three crosses suggest that effective selection for SLA and HI could be practiced even in the early generations in all the crosses. The importance of $\mathrm{i}$ type epistasis for SLA and $\mathrm{HI}$ in all the crosses except Chico $\times$ ICGV 86031 for SLA indicated that the selection and breeding procedures in these crosses can be modified to exploit this fixable epistasis by delaying the selection to later generations, and by maintaining large populations prior to selection to provide maximum opportunity for advantageous combinations of genes to occur.

Results of the present study are based on only one season's data and may be biased due to genotype $x$ environment interactions. However, they have implications for breeding and selection procedures for SLA and HI in groundnut. In general, additive gene effects are likely to play more important role in the inheritance of quantitative traits in groundnut, if the selected parents are less divergent (Isleib \& Wynne, 1983).

\section{References}

Anon. 2000. FAOSTAT database. http://www/FAO.ORG Bailey W K, Hammons R O. 1975. Registration of Chico peanut germplasm. Crop Science 15:105.

Cavalli L L. 1952. An analysis of linkage in quantitative inheritance. In Quantitative inheritance, pp. 35-144. Eds E C R Reeve and C H Waddington. London: HMSO.

Coffelt T A, Seaton M L, Van Scoyoc S W. 1989. Reproductive efficiency of 14 virginia type peanut cultivars. Crop Science 29:1217-1220.

Cukadar-Olmedo B, Miller J F. 1997. Inheritance of stay green trait in sunflower. Crop Science 37:150-153.

Dhopte A M, Zade V R. 1981. Influence of growth habit on harvest index of groundnut and its correlation with yield. Indian Journal of Plant Physiology 24:37-41.

Duncan W G, McCloud D E, McGraw R L, Boote K J. 1978. Physiological aspects of peanut yield improvement. Crop Science 18:1015-1020.

Dwivedi S L, Nigam S N, Chandra S, Ramraj V M. 1998. Combining ability of biomass and harvest index under shortand long-day conditions in groundnut. Annals of Applied Biology 133:237-244.

Dwivedi S L, Reddy D V R, Nigam S N, Ranga Rao G V, Wightman J A, Amin P W, Nagabhushnam G V S, Reddy AS, Scholberg E, Ramraj V M. 1993. Registration of ICGV 86031 peanut germplasm. Crop Science 33:220.

Farquhar G D, O'Leary M H, Berry J A. 1982. On the relationship between carbon isotope discrimination and the intercellular carbon dioxide concentration in leaves. Australian Journal of Plant Physiology 9:121-137.

Hubick K T, Farquhar G D, Shorter R. 1986. Correlation between water-use efficiency and carbon isotope discrimination in diverse peanut (Arachis) germplasm. Australian Journal of Plant Physiology 13:803-816.

Hubick K T, Shorter R, Farquhar G D. 1988. Heritability and genotype $\times$ environment interactions of carbon isotope discrimination and transpiration efficiency in peanut (Arachis hypogaea L.). Australian Journal of Plant Physiology 15:799813.

Isleib T G, Wynne J C. 1983. Heterosis in testcrosses of 27 exotic peanut cultivars. Crop Science 23: 832-841.

Jayalakshmi V, Rajareddy C, Reddy P V, Nageswara Rao R C. 1999. Genetic analysis of carbon isotope discrimination and specific leaf area in groundnut (Arachis hypogaea L.). Journal of Oilseeds Research 16:1-5.

Makne VG. 1992. Diallel analysis for studying the inheritance of branches, developed pods, and harvest index in groundnut. Journal of Maharashtra Agricultural Universities 17:153154.

Mather K, Jinks J L. 1971. Biometrical Genetics. 2nd Edn. London: Chapman and Hall Ltd.

Murty P S S, Reddy P J R, Sankara Reddy G H. 1983. Variation in the physiological parameters of popular groundnut varieties. Madras Agricultural Journal 70:603610 . 
Passioura J B. 1986. Resistance to drought and salinity: avenues for improvement. Australian Journal of Plant Physiology 13:191-201

Sharma V K, Varshney S K. 1995. Analysis of harvest index in groundnut. Journal of Oilseeds Research 12:171-175.

Torres A M, Moreno M T, Cubero J I. 1993. Genetics of six components of autofertility in Vicia faba. Plant Breeding 110:220-228.

Velu G, Gopalakrishnan S. 1985. Habitual and varietal variation in yield, harvest index, and quality characteristics of groundnut. Madras Agricultural Journal 72:518-521.

Wallace D H, Baudoin J P, Beaver J, Coyne D P, Halseth D E, Masaya P N, Munger H M, Myres J R, Silbernagel M, Yourstone K S, Zobel R W. 1993. Improving efficiency of breeding for higher crop yield. Theoretical and Applied Genetics 86:27-40.
Wright G C. 1994. Introduction to 'Selection for water-use efficiency in food legumes': Project background, objectives and output, and scope of workshop. ACIAR Technical Reports 27:14-16.

Wright G C, Hubick K T, Farquhar G D. 1988. Discrimination in carbon isotopes of leaves correlates with water-use efficiency of field-grown peanut cultivars. Australian Journal of Plant Physiology 15:815-825.

Wright G C, Nageswara Rao R C, Farquhar G D. 1994. Water-use efficiency and carbon isotope discrimination in peanut under water deficit conditions. Crop Science 34:9297. 